\title{
ВСТУПНЕ СЛОВО
}

\author{
Юрій Сергійович Шемшученко, \\ директор Інституту держави і права \\ ім. В. М. Кореиького НАН України, академік НАН України
}

\section{ШАНОВНІ КОЛЕГИ! ГОСТІ! НАУКОВЦІ!}

Хочу всіх привітати з нагоди нашої конференції, яка відбувається напередодні 70-річчя Інституту держави і права імені В. М. Корецького НАН України.

Декілька слів про цю подію. Враховуючи вищезазначене про ії значущість. На даний час Інститут $€$ провідною науково-дослідною академічною правознавчою установою, здобутки якого широко відомі як в нашій країні, так і поза ï межами. У його 9 відділах працює близько 100 наукових співробітників. Серед них 14 академіків і членів-кореспондентів НАН України та Національної академії правових наук України, 8 лауреатів державних премій України, 6 Заслужених діячів науки і техніки, 11 Заслужених юристів України тощо. Минулого року усі відділи за результатами атестації одержали найвищий атестаційний показник професійності - рівень «А».

За 70 років свого існування в Інституті було підготовлено і видано понад 500 наукових монографій в т. ч. 6-томна «Юридична енциклопедія», 10-томна «Антологія української юридичної думки», десятки підручників з усіх галузей права тощо. Інститут носить ім'я В. М. Корецького. Щороку ми проводимо з Міністерством юстиції України тиждень права, присвячений В. М. Корецькому. Підтримуємо тісний творчий контакт з даним Міністерством.

Останні роки головним чином пов'язані з удосконаленням зв'язків науки і практики. При цьому йдеться не тільки про юридичну науку, а й політологію. Адже закон - $є$ захід політичний. Саме тому свого часу ми утворили в Інституті відділ політичних досліджень, у рамках якого зараз успішно досліджуються проблеми юридичної політології. Йдеться, зокрема, про проблеми політики і права, тенденції у розвитку політичної доктрини тощо. Важливою $є$ й науково-експертна діяльність Інституту. Тут активно діє Науково-експертна рада, яка щороку надає близько 200 наукових висновків для державних органів, органів місцевого самоврядування, Конституційного Суду, громадян України. Це сприяє зміцненню правової держави і громадянського суспільства в Україні. Як і раніше, ми значну увагу надаємо дослідженню традиційних галузей права - цивільного, кримінального, адміністративного тощо. Разом з тим започаткували й дослідження нових галузей. Йдеться, наприклад, про екологічне право. Тут ми маємо свої пріоритети. Отримали широкий розвиток і дослідження проблем космічного права. 3 цією метою було утворено Міжнародний центр космічного права при НАН України, а також відповідний відділ у складі Інституту. Ми видали перший в Україні підручник «Космічне право», ряд монографій, а також 5-томний збірник «Космічне законодавство країн світу». У своїй творчій діяльності ми виходимо з того, що юридична наука має працювати на випередження. Вона має прокладати шлях для практики, бути надійним захисником прав людини і громадянина.

Проте, слід погодитися з тим, що існує багато проблем у вітчизняній нормотворчій діяльності, зокрема:

1) наявність великої кількості правових актів, що регулюють однотипні правові відносини;

2) дублювання нормативно правових приписів у різних нормативно-правових актах, що знаходяться не рідко у ієрархічній послідовності;

3) декларування в нормативно-правових актах, прав і обов'язків (повноважень) без встановлення належних механізмів їх реалізації тощо.

Втім, нормотворчість на усіх рівнях від вищих органів державної влади (загальна нормотворчість), центральних органів виконавчої влади (відомча нормотворчість), місцевих органів виконавчої влади (місцева нормотворчість) до нормотворчості керівників підприємств, установ, організацій (локальна нормотворчість) повинна дієво забезпечувати права, свободи і законні інтереси людини.

Тому правовий моніторинг, правова аналітика, правовий аналіз, як і інші інструменти правових досліджень, відіграють величезне значення в житті держави, громадянського суспільства і пересічної людини. Тож бажаю всім плідної роботи, успішних виступів, конструктивних дискусій.

DOI: $10.33 .66 .3 / 2524-017 X-2019-10-8-8$ 